\title{
The Determinants of Aid in the Post-Cold War Era
}

\author{
Subhayu Bandyopadhyay and Howard J. Wall
}

\begin{abstract}
The authors estimate the responsiveness of aid to recipient countries' economic and physical needs, civil/political rights, and government effectiveness. They look exclusively at the postCold War era and use fixed effects to control for the political, strategic, and other considerations of donors. They find that aid and per capita income have been negatively related, while aid has been positively related to infant mortality, rights, and government effectiveness. (JEL F35)
\end{abstract}

Federal Reserve Bank of St. Louis Review, November/December 2007, 89(6), pp. 533-47.

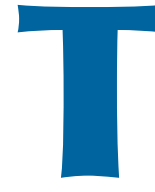

his paper estimates the extent to which aid, or official development assistance, is related to measures of recipient countries' physical and economic needs, civil/political rights, and government effectiveness. We examine the post-Cold War era, which thus far has not been the focus of substantial research, although there are fairly obvious reasons to believe that the differences in the geopolitics between the pre- and post-Cold War eras amount to a structural difference in terms of aid allocation.

There are many reasons why we should be interested in the determinants of aid levels. First, because aid is an important means by which donor countries and agencies try to alleviate poverty, we should care about whether aid is being directed towards those most in need of it. Similarly, we should also be interested in whether aid tends to go more towards where it might be most effective, as measured by the effectiveness of the recipient government in making use of the aid or in fostering economic growth. ${ }^{1}$

Early studies of aid allocation tend to apply some version of the McKinlay and Little (1979) dichotomy-recipient needs versus donor interests-to models of aid allocation. As laid out by Maizels and Nissanke (1984, p. 879), in the recipient-needs model, "aid is given to compensate for the shortfalls in domestic resources," whereas in the donor-interests model, aid serves donors' "political/security, investment, and trade interests." Maizels and Nissanke found that multilateral aid tended to follow the recipient-needs model, while bilateral aid tended to follow the donor-interests model, although there were elements of each model in both types of aid. ${ }^{2}$

Subsequent research has added two other categories—civil/political rights and recipientcountry institutions—-to the McKinlay and Little dichotomy, although not all papers deal with all four categories simultaneously. ${ }^{3}$ For example,

\footnotetext{
1 See Boone (1996) and Kosack (2003) for discussions of the links between institutions and aid effectiveness. Also, in Burnside and Dollar (2000 and 2004) the impact of aid on growth depends on the quality of recipient-state institutions and policies; although Easterly, Levine, and Roodman (2004) and Rajan and Subramanian (2005) found little or no evidence of this.

2 See also Dowling and Hiemenz (1985).

${ }^{3}$ Neumayer (2003b) provided an excellent survey of the literature.
}

Subhayu Bandyopadhyay was an associate professor at West Virginia University and a research fellow at IZA (Institute for the Study of Labor) at the time this paper was written; he is now a research officer at the Federal Reserve Bank of St. Louis. Howard J. Wall is an assistant vice president and economist at the Federal Reserve Bank of St. Louis. This paper was written while Howard Wall was a visiting scholar at the Institute for Economic and Monetary Studies at the Bank of Japan; he is grateful for their resources and hospitality. The authors also thank Kristie Engemann for her research assistance. This article was published as chapter 17 in Theory and Practice of Foreign Aid, volume 1 (edited by Sajal Lahiri and published by Elsevier in May 2007). It is reprinted here with permission from the publisher.

(C) 2007, Elsevier, reprinted with permission. 
Wall (1995) found that countries with lower per capita incomes tended to receive higher levels of aid per capita, although aid was not related to infant mortality or to civil/political rights. On the other hand, Trumbull and Wall (1994) found that, when recipient-country fixed effects are included to control for donor interests, aid levels respond to changes in infant mortality and rights, but not to changes in per capita income.

Alesina and Dollar (2000) included a variety of variables, such as trade openness, colonial history, and friendliness at the United Nations (UN), to capture the effects of donor interests. They concluded that, although aid is related to per capita income and democracy (but not to civil rights), it is as much directed by political and strategic considerations. A pair of recent studies focus on the institutions of the recipient countries: Alesina and Weder (2002) found that corrupt governments do not tend to receive less aid than "clean" governments, and Dollar and Levin (2004) found that, over time, aid has become directed more towards countries with sound institutions and policies, although there were differences across bilateral donors and multilateral agencies.

In a series of papers, Eric Neumayer provided a detailed analysis of the relationship between aid and civil/political rights. ${ }^{4}$ In Neumayer (2003a), UN agencies were found to respond to economic and possibly civil/political-development needs, but not necessarily to political freedom and corruption. There is some evidence in Neumayer (2003b) that high levels of rights or improvements in rights mean higher bilateral aid, but Neumayer concluded that the role of rights is limited and did not increase after the end of the Cold War. Finally, Neumayer (2003c) found that although respect for rights tends to play a role at the selection stage, there is significant inconsistency in the application of rights to the determination of the levels of bilateral aid.

This paper focuses on three of the four categories of aid determinants-recipient needs, civil/ political rights, and recipient-government effectiveness-while following Trumbull and Wall (1994) in using fixed effects to control for the

4 See also Neumayer (2003d). fourth category, the strategic and political interests of donor countries. The advantage of this approach is that, because we do not have to choose strategic/ political variables explicitly, we avoid the problems that can arise if there are excluded variables that determine both the level of aid and one or more of our other explanatory variables. This means that we do not run the risk of heterogeneity bias because of omitted time-invariant factors related to history, geography, culture, etc. If these factors, which are primarily the sort of factors that are used to measure donor interests, are not completely specified and they are correlated with aid and one or more of the included explanatory variables, then heterogeneity bias is the result. The relative shortness of our sample provides comfort that fixed effects provide a useful control for donor interests.

While our fixed-effects approach follows Trumbull and Wall (1994), there are two main differences between our analysis and theirs. The first and more obvious difference is that we are able to look at a more recent time period, so our results should be more relevant for understanding the present situation. Second, because we use a quadratic rather than a log-linear functional form, we are able to provide a richer analysis of the functional relationship between aid and the variables of interest.

\section{EMPIRICAL MODEL AND DATA}

Our dependent variable, Aid $_{i t}$, is real net official development assistance from all sources for country $i$ in year $t$. Data are taken from the World Bank and are denominated in constant 2000 U.S. dollars. We estimate the following reduced-form regression, in which $i$ denotes the recipient country and $t$ denotes time:

$$
\begin{aligned}
& \text { Aid }_{i t}=\alpha_{0}+\alpha_{i}+\gamma_{t} \\
& +\beta_{1} \text { GDPpercapita }_{i t}+\beta_{2} \text { GDPpercapita }_{i t}^{2} \\
& +\delta_{1} \text { InfantMortality }_{i t}+\delta_{2} \text { InfantMortality }_{i t}^{2} \\
& +\lambda \text { Civil / PoliticalRights } \\
& + \text { WGovernmentEffectiveness } \text { - }_{1} \text { Population }_{i t}+\theta_{2} \text { Population }_{i t}^{2}+\varepsilon_{i t} .
\end{aligned}
$$


The intercept includes a component, $\alpha_{0}$, that is common to all recipient countries, and a recipientcountry fixed effect, $\alpha_{i}$, that is specific to each recipient country but fixed over the sample period. We also include a period effect, $\gamma_{t}$, that is common to all countries in the sample but varies over time. Our two recipient-needs variables are real gross domestic product (GDP) per capita and infant mortality, both of which are from the World Bank. ${ }^{5}$ We think it is important to include both of these variables because each captures a different element of recipient need: Per capita income captures economic need while infant mortality represents physical need. Although clearly correlated in the long run, economic and physical needs do not necessarily move in the same direction over shorter periods of time, and aid is clearly meant to respond to both.

For our rights variable, we use the sum of the civil liberties and political rights indices produced by Freedom House. For each category, the Freedom House index scores countries from 1 to 7 , with 1 being the most free and 7 being the most restrictive. For the regression here, we have reversed the order, so that the level of rights increases with the index. Our measure of recipientgovernment effectiveness is from the World Bank's Governance Indicators (see Kaufmann, Kraay, and Mastruzzi, 2006), which scores governments between -2.5 and 2.5 on the basis of the competence of their bureaucracy and the quality of public service delivery. Finally, we include recipientcountry population to capture differences in recipient-country size. The quadratic specification enables us to consider the extent of population bias, by which the per capita aid allocation falls with country size: A concave relationship between the level of aid and population is consistent with a population bias.

We have three years of data, 1995, 2000, and 2003. After eliminating observations for which data are incomplete and countries for which there are fewer than two useful observations, we are left with 135 recipient countries and 395 observations. The sample statistics for all variables are

5 Per capita GDP is converted into U.S. dollars using purchasingpower-parity exchange rates.

\section{Table 1}

\section{Sample Statistics}

\begin{tabular}{lrc} 
& Mean & $\begin{array}{c}\text { Standard } \\
\text { deviation }\end{array}$ \\
\hline Real aid (\$ millions) & 356.93 & 439.26 \\
Real GDP per capita (\$ thousands) & 4.96 & 4.54 \\
Infant mortality & 52.33 & 39.56 \\
Civil/political rights & 8.29 & 3.39 \\
Government effectiveness & -0.30 & 0.67 \\
Population (millions) & 36.25 & 139.51 \\
\hline
\end{tabular}

provided in Table 1, and the country averages of the variables are provided in the data appendix.

The distribution of average aid to countries in our sample is illustrated by Figure 1. The mean country in our sample received \$357 million per year in aid, although the median country, Yemen, received only \$226 million, indicating that aid was skewed toward a few countries. Specifically, there were 13 countries that received more than $\$ 1$ billion in aid per year, the top five of which were China, Poland, Congo, Indonesia, and Russia. At the other extreme, four countries in our sample-Singapore, the Bahamas, St. Kitts, and Kuwait-averaged less than $\$ 10$ million in aid receipts per year.

Figure 2 provides a different angle on the distribution of aid across countries by showing the shares of total aid received. The three countries receiving the most aid-China, Poland, and Congo-alone accounted for 13 percent of the total. These countries plus the 10 countries that received between $\$ 900$ million and $\$ 1,800$ million per year accounted for a larger share of aid (40 percent) than did the 102 countries that received less than $\$ 450$ million per year.

To get a clear picture of how aid is distributed, we need to control for the sizes of the recipient countries, so Figure 3 plots the within-country averages of our explanatory variables against per capita aid. These plots serve to illustrate the simple correlations between the dependent and independent variables as well as the distribution of the values of our independent variables. 
Figure 1

\section{Distribution of Average Aid}

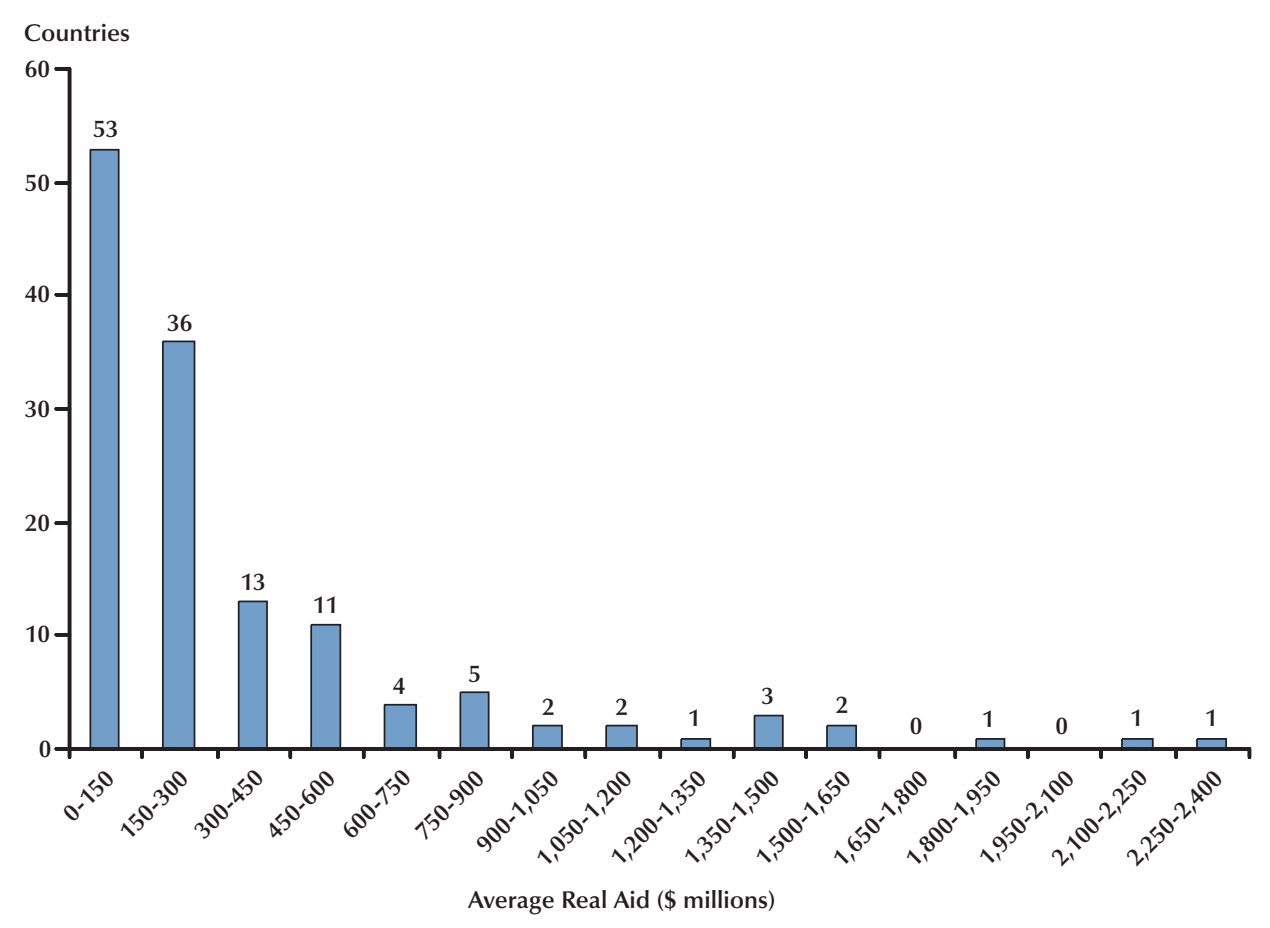

Figure 2

Shares of World Aid

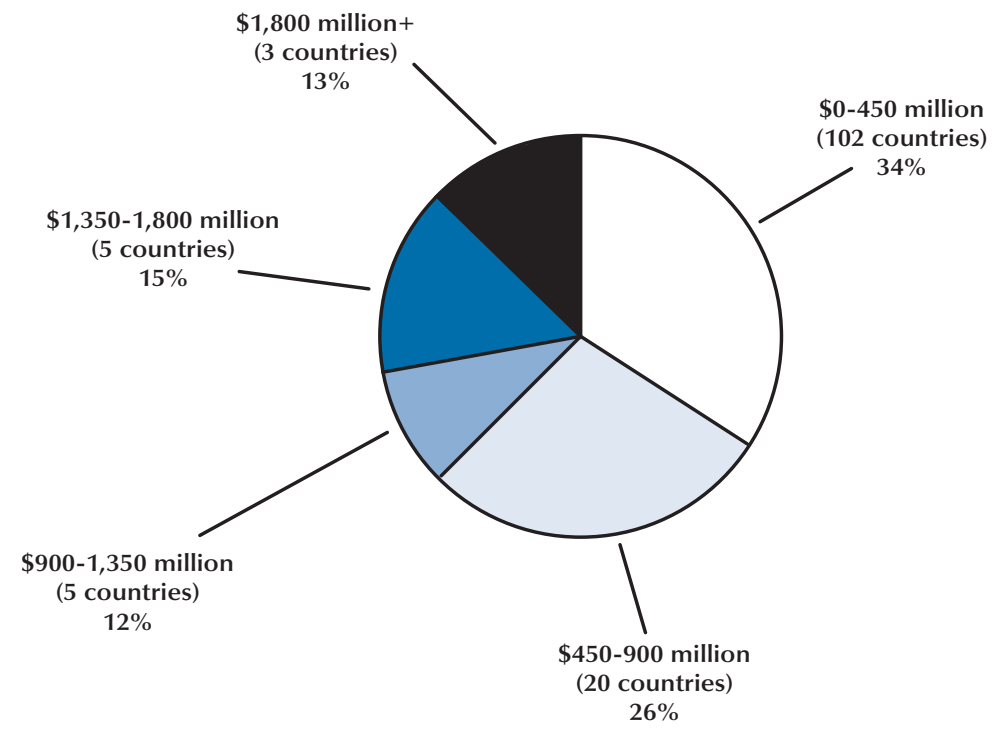




\section{Figure 3}

\section{Aid Per Capita and the Explanatory Variables (country averages)}
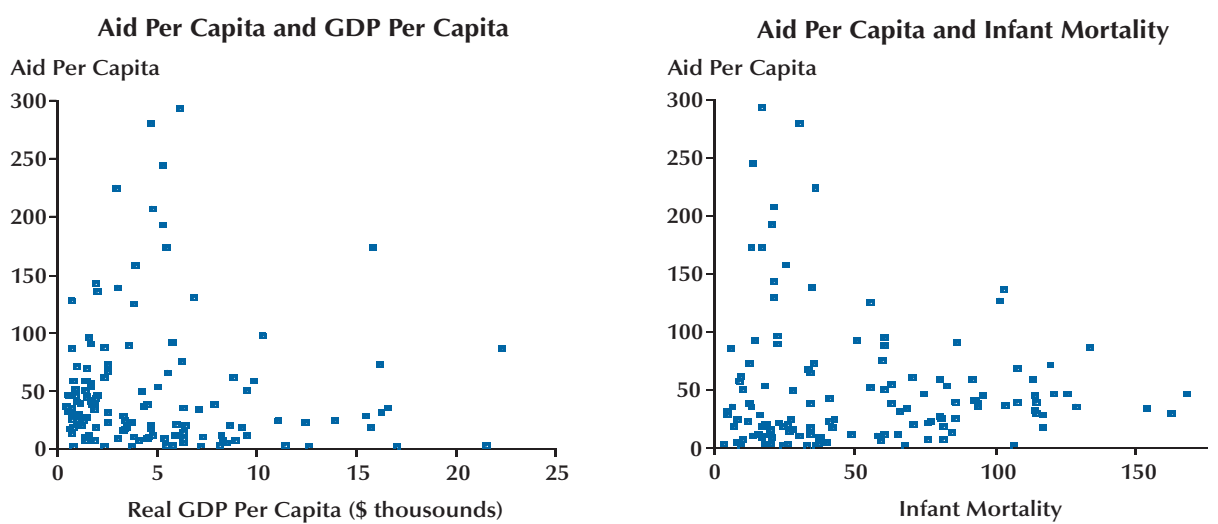

Aid Per Capita and Civil/Political Rights Aid Per Capita

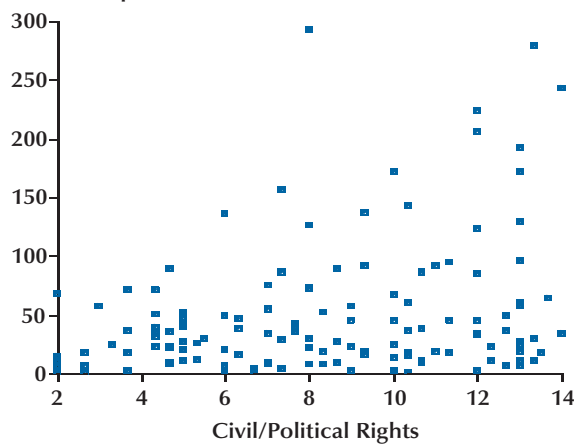

Aid Per Capita and Government Effectiveness Aid Per Capita

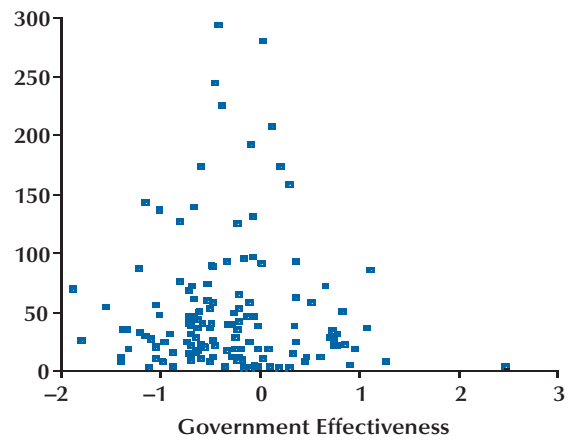

Aid Per Capita and Population

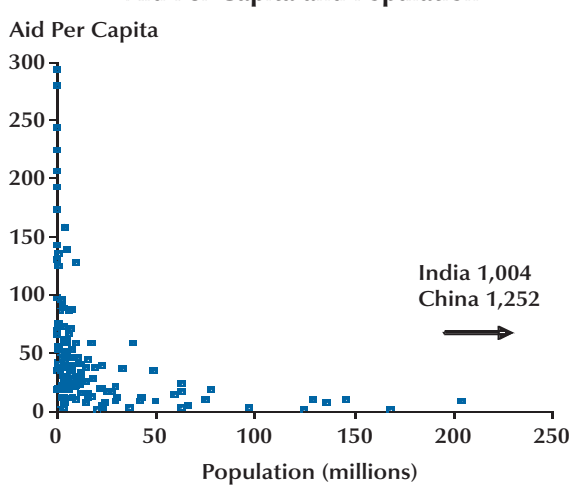


Note that the vast majority of our recipient countries had average per capita incomes around or below $\$ 10,000$, although there were nine countries with average incomes above $\$ 15,000$ : Israel and Singapore were the richest of these countries, followed by Kuwait, Malta, Slovenia, Bahrain, Seychelles, the Bahamas, and the Czech Republic. There was a general tendency for relatively poor countries to receive more aid per capita, but some countries' receipts were well in excess of the sample average. For example, eight countriesTonga, Cape Verde, Dominica, Vanuatu, Samoa, St. Vincent, St. Lucia, and Seychelles-saw average per capita aid that was more than two standard deviations above the mean. At the other extreme, six countries-Nigeria, China, Brazil, Kuwait, India, and Saudi Arabia—received less than $\$ 2$ per capita.

From the second panel in Figure 3, it is clear that the eight countries listed above as having the highest per capita aid allocation also tended to have relatively low rates of infant mortality. Also note from this panel that there was a negative correlation between average per capita aid and infant mortality; the three countries with the highest average infant mortality rates-Sierra Leone, Niger, and Angola-received only about the average level of aid per capita.

As the third panel of Figure 3 shows, our civil/political rights variable was pretty evenly distributed across the countries in our sample, and there was a general positive correlation between per capita aid allocation and rights. In fact, of the eight countries listed above as receiving the most aid per person, only two-Tonga and Seychelles-had civil/political rights scores below 12. According to the fourth panel, there was no apparent correlation between aid per capita and the effectiveness of recipient-country governments. Also, the governments were clustered below the mediocre score of +1 , with Singapore as the lone really effective government. Still, there is significant variation among countries, with many scoring worse than -1 . Finally, consistent with the notion of population bias, the fifth panel illustrates the tendency for the smallest (largest) countries to receive the highest (lowest) levels of aid per capita.

\section{EMPIRICAL RESULTS}

While the distributions and correlations discussed above are suggestive, they are, of course, inadequate for addressing whether aid is responsive to needs, rights, government effectiveness, and/or donor interests. Therefore, we need to control for all four categories of variables simultaneously, as in our regression equation above, to determine the influence of each category individually on aid.

We first estimate the model under the restriction that fixed effects, which we use to control for donor interests and other omitted factors, do not matter $\left(\alpha_{i}=0 \forall i\right)$, and then without these restrictions. So that we can control for recipientspecific heteroskedasticity, we estimate both models with feasible generalized least squares. Table 2 provides the regression results for both models, while Table 3 provides the Wald tests for the joint significance of those explanatory variables with quadratic specifications. For each estimation, we have produced a set of figures (Figures 4 and 5) to illustrate the shapes of the estimated relationships between aid and the five explanatory variables. Table 4 reports for the two models the effect on aid of one-standard-deviation increases in each of the five explanatory variables for the average country.

\section{Model without Fixed Effects}

In the estimation without fixed effects, the effects of all of our explanatory variables except for the civil/political rights variable are statistically different from zero. This is according to the $t$-statistics for the coefficients on the variables with linear specifications and according to the Wald tests in Table 3 for the variables with quadratic specifications. Thus, according to this model, the level of aid is responsive to recipient needs (as measured by per capita income and by infant mortality), the effectiveness of recipient-country governments, and population, but not to civil/ political rights.

For the nature of these relationships, refer to Figure 4, which illustrates the U-shapes of the relationships between aid and both needs variables; i.e., from high levels of need (low income 


\section{Table 2}

\section{Regression Results: Dependent Variable $=$ Level of Real Aid}

\begin{tabular}{|c|c|c|c|c|c|c|}
\hline & \multicolumn{3}{|c|}{ No fixed effects } & \multicolumn{3}{|c|}{ With fixed effects } \\
\hline & Coefficient & Standard error & $t$-Statistic & Coefficient & Standard error & $t$-Statistic \\
\hline Common intercept & $564.693 *$ & 48.850 & 11.56 & $400.684^{*}$ & 126.088 & 3.18 \\
\hline Recipient fixed effects & No & & & Yes & & \\
\hline 2000 dummy & $-56.913^{*}$ & 12.688 & -4.49 & $-82.195^{*}$ & 6.984 & -11.77 \\
\hline 2003 dummy & -18.343 & 12.985 & -1.41 & -11.714 & 10.667 & -1.10 \\
\hline Real GDP per capita & $-78.178^{*}$ & 5.955 & -13.13 & $-116.490^{*}$ & 8.848 & -13.17 \\
\hline Real GDP per capita squared & $2.646^{*}$ & 0.268 & 9.86 & $3.927^{*}$ & 0.387 & 10.14 \\
\hline Infant mortality & $-3.053^{*}$ & 0.693 & -4.41 & $3.632^{*}$ & 1.291 & 2.81 \\
\hline Infant mortality squared & $0.022^{*}$ & 0.004 & 5.75 & $-0.015^{*}$ & 0.008 & -1.95 \\
\hline Civil/political rights & 0.212 & 1.841 & 0.12 & $8.940^{*}$ & 2.486 & 3.60 \\
\hline Government effectiveness & $114.432^{*}$ & 13.934 & 8.21 & $82.453^{*}$ & 12.856 & 6.41 \\
\hline Population (millions) & $7.497^{*}$ & 0.394 & 19.01 & $13.419^{*}$ & 2.815 & 4.77 \\
\hline Population squared & $-0.005^{*}$ & 0.000 & -10.78 & $-0.012^{*}$ & 0.002 & -6.95 \\
\hline Log likelihood & & $-2,563.56$ & & & $-2,264.07$ & \\
\hline Number of observations & & 395 & & & 395 & \\
\hline Number of recipient countries & & 135 & & & 135 & \\
\hline Estimated coefficients & & 11 & & & 145 & \\
\hline
\end{tabular}

NOTE: Estimated using feasible generalized least squares, allowing for recipient-specific heteroskedasticity; ${ }^{*}$ indicates statistical significance at the 10 percent level.

\section{Table 3}

\section{Wald Tests of Joint Significance}

\begin{tabular}{lrrrrr} 
& \multicolumn{2}{c}{ No fixed effects } & & \multicolumn{2}{c}{ With fixed effects } \\
\cline { 2 - 4 } \cline { 5 - 6 } & \multicolumn{1}{c}{$\chi^{2}$} & Probability $>\chi^{2}$ & & $\chi^{2}$ & \multicolumn{2}{c}{ Probability > $\chi^{2}$} \\
\hline Real GDP per capita & 202.53 & 0.000 & & 174.00 & 0.000 \\
Infant mortality & 46.40 & 0.000 & 8.37 & 0.015 & 0.000 \\
Population & 388.91 & 0.000 & 49.34 & \\
\hline
\end{tabular}

and high infant mortality), an increase in need brings an increase in aid. On the other hand, at low levels of need, an increase in need brings a decrease in aid. This rather peculiar result is not much of a concern when looking at per capita income, however, because there are very few countries with incomes on the upward-sloping portion of the relationship. As reported in Table 4, a one-standard-deviation increase in per capita GDP (about \$4,500) from the average (about $\$ 5,000)$ means a decrease in aid of $\$ 90$ million. The U-shape of the relationship for infant mortality is more troubling because the majority of countries have infant mortality levels that would place them on the downward-sloping portion of the relationship (see Figure 3). For example, for 


\section{Figure 4}

\section{Relationships without Fixed Effects}
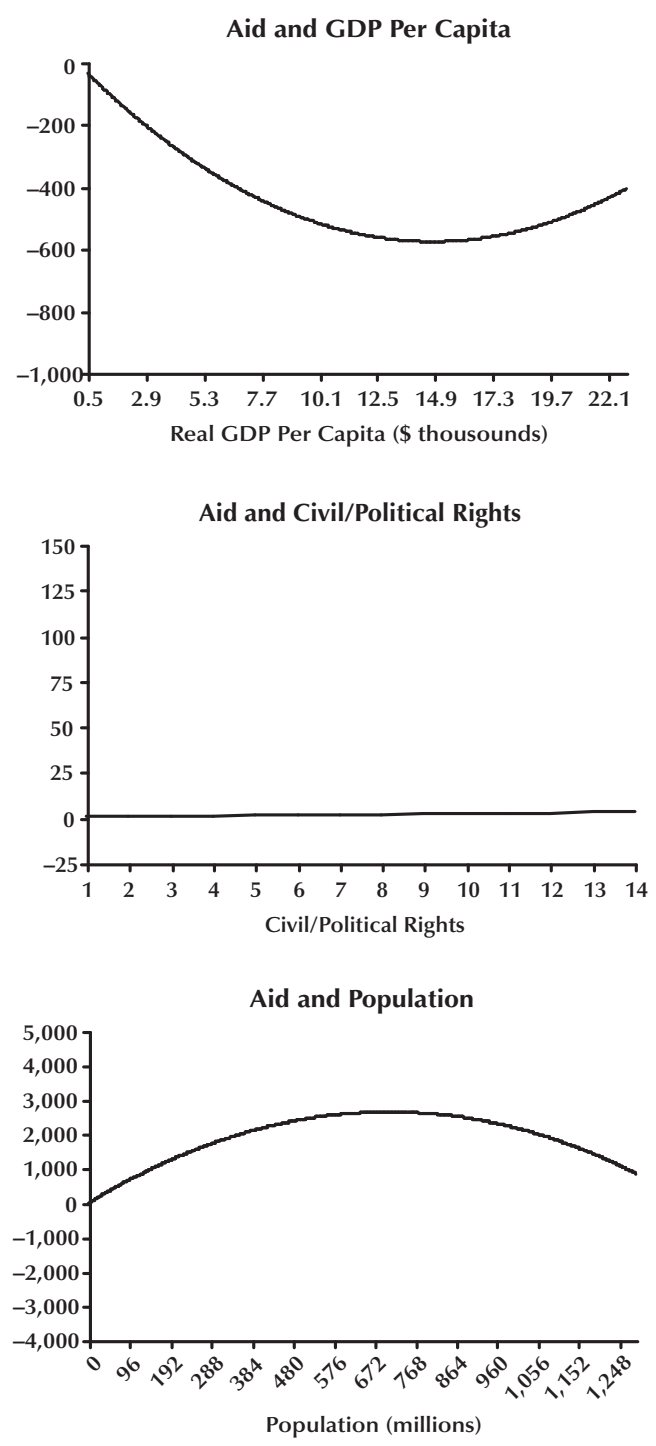
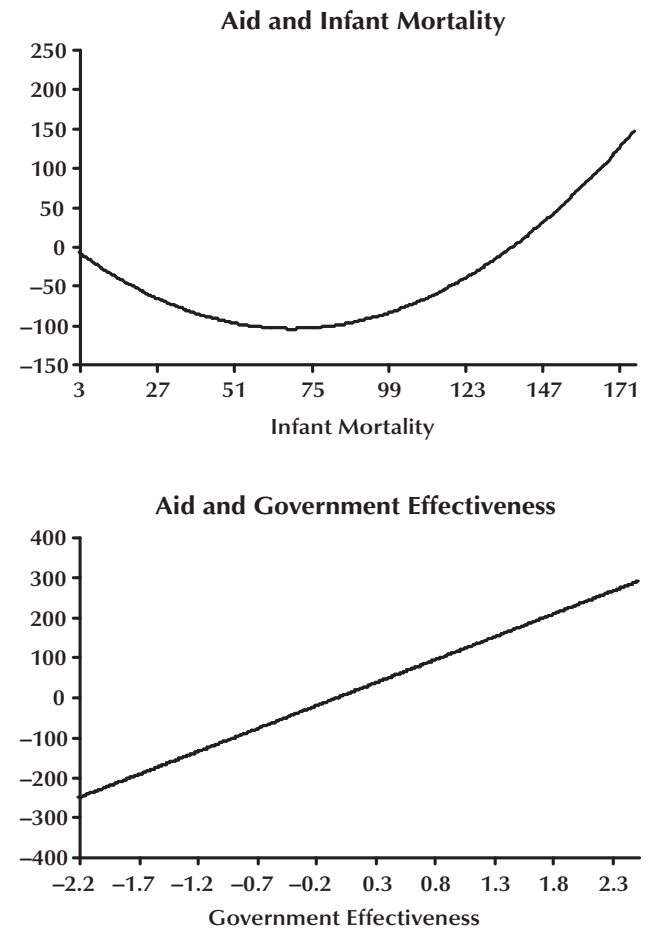

a country with the sample average rate of infant mortality (about 52), a one-standard-deviation increase in infant mortality (about 40) means a decrease in aid of \$19 million.

The two other statistically significant explanatory variables are worth noting. First, in this model, aid is fairly responsive to government effectiveness: The difference between the leasteffective government and the most-effective gov- ernment is close to $\$ 550$ million. Put another way, a one-standard-deviation increase from the average level of government effectiveness $(-0.30)$ to the still-mediocre level of 0.37 means a $\$ 75$ million increase in aid. And, finally, the hill shape of the relationship between aid and population confirms the oft-observed population bias; i.e., per capita aid falls with population. In fact, the bias is strong enough that for countries with 


\section{Figure 5}

\section{Relationships with Fixed Effects}
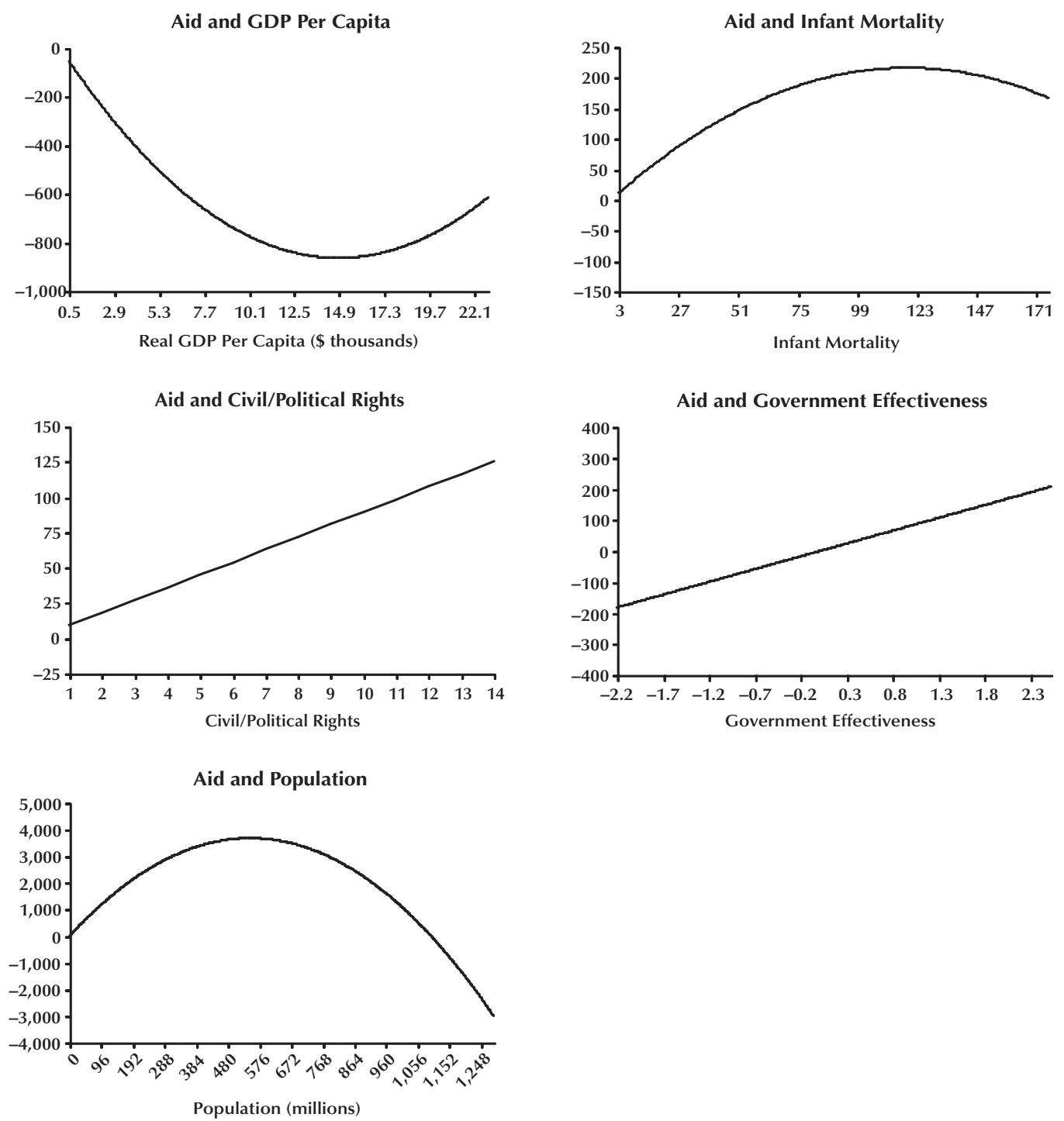

populations above around 700 million (just India and China), an increase in population means a decrease in the level of aid, not just per capita aid.

\section{Model with Fixed Effects}

When we do not impose the restrictions that the fixed effects are all zero (i.e., the intercepts are the same for all recipients), we find that all five explanatory variables are statistically signifi- cant in explaining levels of aid. Further, a likelihood-ratio test easily rejects the null hypothesis that the fixed effects are all zero, meaning that this is the statistically preferred model. Because there are no theory-based reasons to impose these restrictions, it is also the preferred model in terms of theory. The rejection of these restrictions on the fixed effects has important implications for our interpretation of the relationships between 


\section{Table 4}

\section{Responsiveness of Aid to Explanatory Variables}

\begin{tabular}{lcc} 
& $\begin{array}{c}\text { No } \\
\text { fixed effects }\end{array}$ & $\begin{array}{c}\text { With } \\
\text { fixed effects }\end{array}$ \\
\hline Real GDP per capita & -90 & -135 \\
Infant mortality & -19 & 27 \\
Civil/political rights & 1 & 29 \\
Government effectiveness & 75 & 54 \\
Population & 1,013 & 1,734
\end{tabular}

NOTE: Change in aid (\$ millions) for the average country from a one-standard-deviation increase in the explanatory variable.

aid and the explanatory variables and highlights the importance of controlling for donor interests.

Comparing Figures 4 and 5, for which axes in corresponding figures have the same scale, it is clear that the estimated relationships between aid and each of the variables differ importantly between the two models. Even though per capita income, infant mortality, government effectiveness, and population are statistically significant in both, the actual responsive of aid differs between models.

The relationship between aid and per capita GDP has the same U-shape as in the previous model, with the upward-sloping portion having very few recipient countries. In this model, however, aid is more responsive to per capita income: A one-standard-deviation increase in per capita GDP means a \$135 million decrease in aid for the average country, which is 50 percent higher than with the previous model (see Table 4).

The relationship between aid and infant mortality differs a great deal between the two models. Recall that in the first model, the relationship was U-shaped and most countries' levels of infant mortality put them on the downwardsloping portion of the curve. But in the preferred model, the relationship is hill-shaped and is upward-sloping for all but a handful of countries. For the average country, a one-standard-deviation increase in infant mortality means a $\$ 27$ million increase in aid. One might expect that the rela- tionship between aid and infant mortality, if positive, would be convex rather than concave as we have found. One reason for the concavity is that, while higher levels of infant mortality indicate greater need, they might also indicate health care systems that are less effective at making use of any money that they receive. If so, donors might then be allocating more of their limited aid budgets to countries with better health care systems, where each dollar of aid might have a larger impact on well-being. At the extreme, for those countries with the very highest levels of infant mortality and least effective health care systems, this concavity might make the relationship between aid and infant mortality a negative one.

An increase in the civil/political rights variable means an increase in aid according to the preferred model, in contrast with the no-fixedeffects model, for which it was statistically insignificant. A one-standard-deviation increase in civil/political rights means an increase in aid of \$29 million. Recipient-government effectiveness matters in both models, although it matters somewhat less in the model with fixed effects. A one-standard-deviation increase in government effectiveness means a $\$ 54$ million increase in aid, which is $\$ 21$ million less than from the first model. Finally, because the estimated relationship between aid and population is concave, we find a population bias, which is somewhat larger than in the first model. Per capita aid falls more than twice as fast in this model, and the peak of the relationship is at a lower population level.

\section{CONCLUSIONS}

In this paper, we have estimated the responsiveness of total aid in the post-Cold War era to the needs, civil/political rights, and government effectiveness of recipient countries. To do so, we used the approach espoused in Trumbull and Wall (1994): to use fixed effects to control for donor interests. We have found that aid in this era generally responded negatively to per capita GDP and positively to infant mortality, rights, and government effectiveness. This is in contrast with much of the existing literature, which, while 
tending to find a negative link between aid and per capita income, has been decidedly more mixed in terms of the other variables.

\section{REFERENCES}

Alesina, Alberto and Dollar, David. "Who Gives Foreign Aid to Whom and Why?" Journal of Economic Growth, March 2000, 5(1), pp. 33-63.

Alesina, Alberto and Weder, Beatrice. "Do Corrupt Governments Receive Less Foreign Aid?" American Economic Review, September 2002, 92(4), pp. 1126-37.

Boone, Peter. "Politics and the Effectiveness of Foreign Aid." European Economic Review, February 1996, 40(2), pp. 289-329.

Burnside, Craig and Dollar, David. "Aid, Policies, and Growth." American Economic Review, September 2000, 90(4), pp. 847-68.

Burnside, Craig and Dollar, David. "Aid, Policies, and Growth: Revisiting the Evidence.” Policy Research Working Paper No. 3251, World Bank, 2004.

Dollar, David and Levin, Victoria. "The Increasing Selectivity of Foreign Aid, 1984-2002.” Policy Research Working Paper No. 3299, World Bank, 2004.

Dowling, J.M. and Hiemenz, Ulrich. "Biases in the Allocation of Foreign Aid: Some New Evidence." World Development, April 1985, 13(4), pp. 535-41.

Easterly, William; Levine, Ross and Roodman, David. "Aid, Policies, and Growth: Comment." American Economic Review, June 2004, 94(3), pp. 774-80.

Kaufmann, Daniel; Kraay, Aart and Mastruzzi, Massimo. "Governance Matters V: Aggregate and Individual Governance Indicators for 1996-2005." Policy Research Working Paper No. 4012, World Bank, 2006.
Kosack, Stephen. "Effective Aid: How Democracy Allows Development Aid to Improve the Quality of Life." World Development, January 2003, 31(1), pp. 1-22.

Maizels, Alfred and Nissanke, Machinko K. "Motivations for Aid to Developing Countries." World Development, September 1984, 12(9), pp. 879-900.

McKinlay, Robert D. and Little, Richard. "The U.S. Aid Relationship: A Test of the Recipient Need and the Donor Interest Models." Political Studies, 1979, 27(2), pp. 236-50.

Neumayer, Eric. "The Determinants of Aid Allocation by Regional Multilateral Development Banks and United Nations Agencies.” International Studies Quarterly, 2003a, 1(47), pp. 101-22.

Neumayer, Eric. "Is Respect for Human Rights Rewarded? An Analysis of Total Bilateral and Multilateral Aid Flows." Human Rights Quarterly, 2003b, 25(2), pp. 510-27.

Neumayer, Eric. "Do Human Rights Matter in Bilateral Aid Allocation? A Quantitative Analysis of 21 Donor Countries." Social Science Quarterly, September 2003c, 84(3), pp. 650-66.

Neumayer, Eric. The Pattern of Aid Giving: The Impact of Good Governance on Development Assistance. London: Routledge, 2003d.

Rajan, Raghuran G. and Subramanian, Arvind. "Aid and Growth: What Does the Cross-Country Evidence Really Show?” NBER Working Paper No. 11513, National Bureau of Economic Research, 2005.

Trumbull, William N. and Wall, Howard J. "Estimating Aid-Allocation Criteria with Panel Data." Economic Journal, July 1994, 104(425), pp. 876-82.

Wall, Howard J. "The Allocation of Official Development Assistance." Journal of Policy Modeling, June 1995, 17(3), pp. 307-14. 
DATA APPENDIX

Country Averages

\begin{tabular}{|c|c|c|c|c|c|c|c|}
\hline Country & $\begin{array}{l}\text { Real aid } \\
\text { per capita (\$) }\end{array}$ & $\begin{array}{c}\text { Real aid } \\
\text { (\$ millions) }\end{array}$ & $\begin{array}{c}\text { Real GDP } \\
\text { per capita } \\
\text { (\$ thousands) }\end{array}$ & $\begin{array}{c}\text { Infant } \\
\text { mortality }\end{array}$ & $\begin{array}{l}\text { Civil/ } \\
\text { political } \\
\text { rights }\end{array}$ & $\begin{array}{r}\text { Government } \\
\text { effectiveness }\end{array}$ & Population \\
\hline Albania & 88.9 & 280.0 & 3.6 & 23.0 & 8.7 & -0.49 & 3.2 \\
\hline Algeria & 8.3 & 247.9 & 5.4 & 38.3 & 4.7 & -0.69 & 30.1 \\
\hline Angola & 33.8 & 410.6 & 1.9 & 154.0 & 4.3 & -1.33 & 12.3 \\
\hline Argentina & 3.1 & 111.8 & 11.5 & 18.7 & 12.0 & 0.11 & 36.5 \\
\hline Armenia & 72.3 & 228.7 & 2.6 & 35.7 & 8.0 & -0.52 & 3.2 \\
\hline Azerbaijan & 22.7 & 182.9 & 2.6 & 77.3 & 4.7 & -0.96 & 8.0 \\
\hline Bahamas & 17.9 & 5.2 & 15.8 & 17.0 & 13.5 & 0.96 & 0.3 \\
\hline Bahrain & 71.9 & 46.0 & 16.2 & 13.0 & 4.3 & 0.66 & 0.7 \\
\hline Bangladesh & 10.1 & $1,297.0$ & 1.5 & 58.3 & 8.7 & -0.59 & 129.7 \\
\hline Belarus & 10.3 & 104.0 & 4.7 & 14.0 & 4.7 & -1.04 & 10.0 \\
\hline Belize & 64.4 & 15.4 & 5.6 & 34.3 & 13.7 & -0.20 & 0.2 \\
\hline Benin & 45.1 & 273.5 & 1.0 & 96.0 & 12.0 & -0.12 & 6.1 \\
\hline Bolivia & 87.0 & 711.1 & 2.4 & 60.7 & 10.7 & -0.47 & 8.2 \\
\hline Botswana & 33.4 & 52.3 & 7.2 & 68.7 & 12.0 & 0.73 & 1.6 \\
\hline Brazil & 1.8 & 299.5 & 7.2 & 36.3 & 10.3 & -0.14 & 168.7 \\
\hline Bulgaria & 34.4 & 275.4 & 6.4 & 13.3 & 12.0 & -0.22 & 8.1 \\
\hline Burkina Faso & 39.5 & 431.8 & 1.0 & 108.0 & 7.7 & -0.49 & 11.1 \\
\hline Burundi & 31.3 & 205.6 & 0.6 & 114.0 & 4.3 & -1.20 & 6.7 \\
\hline Cambodia & 40.3 & 494.0 & 1.8 & 93.3 & 4.3 & -0.57 & 12.4 \\
\hline Cameroon & 37.7 & 565.6 & 1.8 & 94.0 & 3.7 & -0.70 & 14.9 \\
\hline Cape Verde & 279.6 & 119.1 & 4.7 & 31.0 & 13.3 & 0.04 & 0.4 \\
\hline Central African Republic & 29.0 & 101.9 & 1.1 & 115.0 & 7.3 & -1.15 & 3.7 \\
\hline Chad & 27.3 & 206.9 & 1.0 & 117.0 & 5.0 & -0.64 & 7.7 \\
\hline Chile & 6.6 & 97.2 & 9.0 & 10.3 & 12.7 & 1.27 & 15.1 \\
\hline China & 1.8 & $2,252.6$ & 3.8 & 33.0 & 2.7 & 0.19 & $1,252.0$ \\
\hline Colombia & 8.7 & 376.8 & 6.4 & 20.7 & 8.0 & -0.18 & 41.8 \\
\hline Comoros & 54.8 & 29.1 & 1.7 & 63.0 & 7.0 & -1.04 & 0.6 \\
\hline $\begin{array}{l}\text { Congo, Democratic } \\
\text { Republic }\end{array}$ & 34.7 & $1,826.4$ & 0.8 & 129.0 & 7.0 & -1.38 & 48.7 \\
\hline Congo, Republic & 24.5 & 78.5 & 1.0 & 81.0 & 3.3 & -1.79 & 3.4 \\
\hline Costa Rica & 6.9 & 25.2 & 8.4 & 10.7 & 13.0 & 0.46 & 3.7 \\
\hline Cote d'Ivoire & 43.8 & 635.7 & 1.5 & 114.0 & 5.0 & -0.65 & 15.5 \\
\hline Croatia & 17.7 & 79.4 & 9.3 & 7.7 & 10.3 & 0.09 & 4.5 \\
\hline Czech Republic & 27.5 & 282.4 & 15.5 & 5.0 & 13.0 & 0.72 & 10.3 \\
\hline Djibouti & 136.1 & 86.3 & 2.1 & 103.3 & 6.0 & -1.00 & 0.7 \\
\hline Dominica & 243.9 & 17.6 & 5.3 & 14.3 & 14.0 & -0.45 & 0.1 \\
\hline Dominican Republic & 10.6 & 85.9 & 6.0 & 34.7 & 10.7 & -0.28 & 8.3 \\
\hline Ecuador & 15.4 & 186.6 & 3.4 & 28.3 & 10.3 & -0.86 & 12.3 \\
\hline
\end{tabular}




\section{DATA APPENDIX, cont'd}

\section{Country Averages}

\begin{tabular}{|c|c|c|c|c|c|c|c|}
\hline Country & $\begin{array}{c}\text { Real aid } \\
\text { per capita (\$) }\end{array}$ & $\begin{array}{c}\text { Real aid } \\
\text { (\$ millions) }\end{array}$ & $\begin{array}{c}\text { Real GDP } \\
\text { per capita } \\
\text { (\$ thousands) }\end{array}$ & $\begin{array}{c}\text { Infant } \\
\text { mortality }\end{array}$ & $\begin{array}{l}\text { Civil/ } \\
\text { political } \\
\text { rights }\end{array}$ & $\begin{array}{c}\text { Government } \\
\text { effectiveness }\end{array}$ & Population \\
\hline Egypt, Arab Republic & 23.6 & $1,454.0$ & 3.4 & 43.0 & 4.3 & -0.10 & 63.2 \\
\hline El Salvador & 37.9 & 228.0 & 4.6 & 34.7 & 10.7 & -0.28 & 6.1 \\
\hline Equatorial Guinea & 68.7 & 28.9 & 1.5 & 108.0 & 2.0 & -1.89 & 0.4 \\
\hline Eritrea & 51.5 & 209.4 & 1.0 & 56.0 & 4.3 & -0.50 & 4.0 \\
\hline Estonia & 49.9 & 69.0 & 9.6 & 10.3 & 12.7 & 0.84 & 1.4 \\
\hline Ethiopia & 16.2 & $1,024.4$ & 0.7 & 117.0 & 6.3 & -0.63 & 63.1 \\
\hline Fiji & 52.3 & 42.0 & 5.1 & 18.3 & 8.3 & -0.20 & 0.8 \\
\hline Gabon & 75.2 & 84.0 & 6.3 & 60.0 & 7.0 & -0.79 & 1.2 \\
\hline Gambia, The & 40.9 & 52.1 & 1.7 & 92.7 & 5.0 & -0.20 & 1.3 \\
\hline Georgia & 42.2 & 201.5 & 2.0 & 41.0 & 7.7 & -0.62 & 4.8 \\
\hline Ghana & 37.5 & 721.2 & 1.9 & 63.3 & 10.3 & -0.02 & 19.3 \\
\hline Grenada & 129.6 & 13.1 & 6.9 & 21.7 & 13.0 & -0.07 & 0.1 \\
\hline Guatemala & 21.7 & 241.6 & 3.8 & 41.0 & 8.0 & -0.60 & 11.2 \\
\hline Guinea & 39.2 & 276.7 & 1.9 & 115.0 & 5.0 & -0.71 & 7.3 \\
\hline Guinea-Bissau & 86.4 & 115.4 & 0.8 & 133.7 & 7.3 & -1.21 & 1.3 \\
\hline Guyana & 124.5 & 94.2 & 3.9 & 56.0 & 12.0 & -0.23 & 0.8 \\
\hline Haiti & 52.8 & 395.1 & 1.7 & 82.7 & 5.0 & -1.54 & 7.9 \\
\hline Honduras & 66.9 & 419.3 & 2.5 & 34.0 & 10.0 & -0.71 & 6.4 \\
\hline Hungary & 24.2 & 243.4 & 13.9 & 8.5 & 13.0 & 0.76 & 10.1 \\
\hline India & 1.4 & $1,421.4$ & 2.4 & 68.3 & 10.0 & -0.09 & $1,004.2$ \\
\hline Indonesia & 7.7 & $1,573.4$ & 3.1 & 37.3 & 7.0 & -0.23 & 204.6 \\
\hline Iran, Islamic Republic & 2.5 & 154.5 & 5.8 & 37.3 & 3.7 & -0.34 & 63.0 \\
\hline Israel & 85.0 & 526.7 & 22.3 & 6.0 & 12.0 & 1.12 & 6.2 \\
\hline Jamaica & 17.5 & 43.7 & 3.6 & 17.0 & 11.3 & -0.19 & 2.6 \\
\hline Jordan & 157.5 & 768.3 & 4.0 & 25.7 & 7.3 & 0.30 & 4.8 \\
\hline Kazakhstan & 11.3 & 171.3 & 4.8 & 61.0 & 5.0 & -0.70 & 15.3 \\
\hline Kenya & 20.4 & 588.6 & 1.0 & 76.3 & 6.0 & -0.70 & 29.6 \\
\hline Kuwait & 1.7 & 3.5 & 17.1 & 9.7 & 6.7 & 0.29 & 2.1 \\
\hline Kyrgyz Republic & 49.3 & 236.9 & 1.5 & 60.7 & 6.0 & -0.61 & 4.9 \\
\hline Lao PDR & 58.2 & 299.7 & 1.5 & 92.3 & 3.0 & -0.52 & 5.2 \\
\hline Latvia & 37.4 & 89.1 & 7.9 & 13.0 & 12.7 & 0.35 & 2.4 \\
\hline Lebanon & 48.3 & 206.2 & 4.3 & 28.3 & 5.0 & -0.25 & 4.3 \\
\hline Lesotho & 45.7 & 78.3 & 2.1 & 74.7 & 9.0 & -0.05 & 1.7 \\
\hline Lithuania & 61.2 & 215.0 & 8.9 & 10.0 & 13.0 & 0.37 & 3.5 \\
\hline Macedonia, FYR & 91.8 & 186.0 & 5.8 & 15.0 & 9.3 & -0.33 & 2.0 \\
\hline Madagascar & 25.2 & 386.3 & 0.8 & 85.7 & 10.0 & -0.46 & 15.2 \\
\hline Malawi & 45.8 & 463.0 & 0.6 & 120.7 & 10.0 & -0.69 & 10.2 \\
\hline Malaysia & 3.9 & 88.9 & 8.5 & 8.7 & 6.7 & 0.91 & 22.9 \\
\hline
\end{tabular}




\section{DATA APPENDIX, cont'd}

\section{Country Averages}

\begin{tabular}{|c|c|c|c|c|c|c|c|}
\hline Country & $\begin{array}{c}\text { Real aid } \\
\text { per capita (\$) }\end{array}$ & $\begin{array}{c}\text { Real aid } \\
\text { (\$ millions) }\end{array}$ & $\begin{array}{c}\text { Real GDP } \\
\text { per capita } \\
\text { (\$ thousands) }\end{array}$ & $\begin{array}{c}\text { Infant } \\
\text { mortality }\end{array}$ & $\begin{array}{l}\text { Civil/ } \\
\text { political } \\
\text { rights }\end{array}$ & $\begin{array}{l}\text { Government } \\
\text { effectiveness }\end{array}$ & Population \\
\hline Mali & 45.7 & 482.0 & 0.8 & 125.7 & 11.3 & -0.70 & 10.7 \\
\hline Malta & 35.0 & 13.6 & 16.7 & 7.0 & 14.0 & 1.08 & 0.4 \\
\hline Mauritania & 89.8 & 230.5 & 1.7 & 86.7 & 4.7 & 0.02 & 2.6 \\
\hline Mauritius & 19.9 & 22.9 & 8.7 & 18.5 & 13.0 & 0.75 & 1.2 \\
\hline Mexico & 2.8 & 257.8 & 8.2 & 26.5 & 10.0 & -0.01 & 96.7 \\
\hline Moldova & 23.7 & 101.4 & 1.4 & 27.3 & 9.0 & -0.73 & 4.3 \\
\hline Mongolia & 95.1 & 226.6 & 1.6 & 61.0 & 11.3 & -0.15 & 2.4 \\
\hline Morocco & 17.1 & 483.6 & 3.5 & 42.7 & 6.3 & -0.01 & 28.4 \\
\hline Mozambique & 58.2 & $1,002.7$ & 0.9 & 113.3 & 9.0 & -0.47 & 17.4 \\
\hline Namibia & 91.9 & 166.3 & 5.8 & 51.0 & 11.0 & 0.37 & 1.9 \\
\hline Nepal & 19.3 & 433.4 & 1.3 & 71.3 & 8.3 & -0.56 & 22.7 \\
\hline Nicaragua & 138.2 & 685.9 & 3.1 & 35.0 & 9.3 & -0.65 & 5.0 \\
\hline Niger & 29.7 & 312.4 & 0.8 & 163.0 & 8.0 & -0.90 & 10.5 \\
\hline Nigeria & 1.9 & 238.3 & 0.9 & 106.7 & 6.0 & -1.11 & 124.9 \\
\hline Oman & 21.7 & 50.5 & 12.5 & 12.3 & 4.7 & 0.86 & 2.4 \\
\hline Pakistan & 6.4 & 868.9 & 1.9 & 81.7 & 6.0 & -0.50 & 136.3 \\
\hline Panama & 10.6 & 29.5 & 6.0 & 20.3 & 12.3 & -0.21 & 2.8 \\
\hline Papua New Guinea & 60.2 & 295.6 & 2.5 & 70.3 & 10.3 & -0.66 & 5.1 \\
\hline Paraguay & 18.8 & 93.7 & 4.7 & 26.3 & 9.3 & -1.04 & 5.2 \\
\hline Peru & 16.6 & 426.2 & 4.8 & 34.7 & 9.3 & -0.32 & 25.6 \\
\hline Philippines & 10.2 & 752.6 & 3.9 & 31.0 & 10.7 & 0.04 & 75.5 \\
\hline Poland & 57.4 & $2,212.6$ & 9.9 & 9.3 & 13.0 & 0.52 & 38.5 \\
\hline Romania & 19.9 & 441.8 & 6.5 & 19.3 & 11.0 & -0.46 & 22.3 \\
\hline Russian Federation & 10.3 & $1,500.2$ & 7.3 & 17.3 & 7.0 & -0.47 & 145.7 \\
\hline Rwanda & 71.0 & 465.9 & 1.1 & 120.0 & 3.7 & -0.67 & 7.3 \\
\hline Samoa & 206.6 & 35.2 & 4.8 & 21.3 & 12.0 & 0.13 & 0.2 \\
\hline Saudi Arabia & 1.1 & 23.5 & 12.7 & 24.3 & 2.0 & -0.04 & 20.5 \\
\hline Senegal & 57.7 & 523.7 & 1.5 & 80.7 & 9.0 & -0.09 & 9.4 \\
\hline Seychelles & 172.2 & 13.7 & 15.9 & 13.3 & 10.0 & -0.59 & 0.1 \\
\hline Sierra Leone & 46.2 & 229.1 & 0.6 & 168.0 & 6.3 & -1.01 & 5.0 \\
\hline Singapore & 2.7 & 9.6 & 21.5 & 3.5 & 6.0 & 2.47 & 3.8 \\
\hline Slovak Republic & 23.0 & 123.6 & 11.1 & 8.7 & 12.3 & 0.37 & 5.4 \\
\hline Slovenia & 30.2 & 60.1 & 16.3 & 5.0 & 13.3 & 0.79 & 2.0 \\
\hline Solomon Islands & 143.1 & 59.1 & 2.0 & 21.7 & 10.3 & -1.15 & 0.4 \\
\hline South Africa & 11.6 & 500.1 & 9.6 & 49.3 & 13.0 & 0.48 & 43.0 \\
\hline Sri Lanka & 27.6 & 504.6 & 3.3 & 16.7 & 8.7 & -0.25 & 18.3 \\
\hline St. Kitts and Nevis & 96.2 & 4.1 & 10.4 & 23.0 & 13.0 & -0.06 & 0.0 \\
\hline St. Lucia & 172.6 & 25.8 & 5.5 & 17.0 & 13.0 & 0.21 & 0.2 \\
\hline
\end{tabular}




\section{DATA APPENDIX, cont'd}

\section{Country Averages}

\begin{tabular}{|c|c|c|c|c|c|c|c|}
\hline Country & $\begin{array}{c}\text { Real aid } \\
\text { per capita (\$) }\end{array}$ & $\begin{array}{c}\text { Real aid } \\
\text { (\$ millions) }\end{array}$ & $\begin{array}{c}\text { Real GDP } \\
\text { per capita } \\
\text { (\$ thousands) }\end{array}$ & $\begin{array}{l}\text { Infant } \\
\text { mortality }\end{array}$ & $\begin{array}{l}\text { Civil/ } \\
\text { political } \\
\text { rights }\end{array}$ & $\begin{array}{l}\text { Government } \\
\text { effectiveness }\end{array}$ & Population \\
\hline $\begin{array}{l}\text { St. Vincent and the } \\
\text { Grenadines }\end{array}$ & 192.0 & 21.3 & 5.3 & 20.7 & 13.0 & -0.09 & 0.1 \\
\hline Sudan & 11.3 & 358.5 & 1.7 & 65.7 & 2.0 & -1.39 & 31.0 \\
\hline Swaziland & 35.3 & 34.0 & 4.4 & 93.7 & 4.7 & -0.50 & 1.0 \\
\hline Syrian Arab Republic & 15.3 & 233.3 & 3.3 & 20.3 & 2.0 & -0.64 & 15.9 \\
\hline Tajikistan & 17.9 & 110.6 & 0.9 & 81.7 & 3.7 & -1.32 & 6.1 \\
\hline Tanzania & 35.5 & $1,183.9$ & 0.5 & 103.7 & 7.7 & -0.63 & 33.1 \\
\hline Thailand & 13.5 & 805.0 & 6.4 & 27.0 & 10.0 & 0.33 & 59.7 \\
\hline Togo & 26.0 & 107.0 & 1.6 & 80.3 & 5.3 & -1.10 & 4.4 \\
\hline Tonga & 292.9 & 29.0 & 6.2 & 17.3 & 8.0 & -0.42 & 0.1 \\
\hline Tunisia & 20.5 & 197.7 & 6.0 & 23.3 & 5.0 & 0.78 & 9.5 \\
\hline Turkey & 4.2 & 274.8 & 6.3 & 40.3 & 7.3 & -0.04 & 66.6 \\
\hline Turkmenistan & 6.4 & 29.2 & 4.1 & 76.0 & 2.0 & -1.39 & 4.6 \\
\hline Uganda & 38.6 & 877.5 & 1.2 & 86.0 & 6.3 & -0.31 & 22.9 \\
\hline Ukraine & 8.0 & 397.8 & 4.5 & 17.3 & 8.3 & -0.70 & 49.8 \\
\hline Uruguay & 10.9 & 35.6 & 8.3 & 15.7 & 13.3 & 0.61 & 3.3 \\
\hline Uzbekistan & 6.2 & 153.5 & 1.5 & 59.3 & 2.7 & -0.96 & 24.3 \\
\hline Vanuatu & 224.2 & 41.9 & 3.0 & 36.3 & 12.0 & -0.38 & 0.2 \\
\hline Venezuela, RB & 2.8 & 67.3 & 5.5 & 20.0 & 9.0 & -0.87 & 24.0 \\
\hline Vietnam & 18.1 & $1,420.6$ & 2.0 & 24.7 & 2.7 & -0.23 & 77.6 \\
\hline Yemen, Republic & 13.1 & 226.0 & 0.8 & 85.0 & 5.3 & -0.70 & 17.3 \\
\hline Zambia & 126.7 & $1,177.6$ & 0.8 & 102.0 & 8.0 & -0.80 & 9.7 \\
\hline Zimbabwe & 30.3 & 355.9 & 2.6 & 66.5 & 5.5 & -0.69 & 12.1 \\
\hline
\end{tabular}


